\title{
From initial dissemination to consolidated impact: the concept of crisis in the field of tourism
}

\author{
Concepción Foronda-Robles $^{1}$ • Luis Galindo-Pérez-de-Azpillaga ${ }^{1}$
}

Received: 12 January 2016/Published online: 9 July 2016

(C) Akadémiai Kiadó, Budapest, Hungary 2016

\begin{abstract}
Bibliometric indicators, used appropriately with other indicators, provide a valuable tool for the evaluation of scientific activity. The article focuses on the review of the scientific literature on crisis and tourism by means of these indicators, using sources provided by the Institute for Scientific Information. The aim is to prove the consolidation of this field by designing a Thematic Level of the Field (TLF) that demonstrates its continuity, collaboration, visibility and impact, while identifying any trends and changes. Bibliographic citations have been obtained by examining information from the Web of Science, using the titles of articles from 1956 to 2013 from the databases of the Social Sciences Citation Index and the Science Citation Index Expanded. The end product is the result of processing this information with different proximity measurements and the application of weighting factors, which lead to the creation of the TLF, classified according to different value-words.
\end{abstract}

Keywords Indicators · Bibliometrics · Consolidation · Crisis · Tourism

\section{Introduction}

The global economic crisis is not a new concept and there are a great number of related bibliographic references that have appeared at different moments in time. The Great Depression, the seventies and the nineties are perhaps the prime examples. When the crisis is referred to these days, in most cases there is mention of the negative effect that it has on

Concepción Foronda-Robles

foronda@us.es

Luis Galindo-Pérez-de-Azpillaga

lgalindo@us.es

1 Departamento de Geografía Humana, Universidad de Sevilla, María de Padilla s/n, 41004 Seville, Spain 
the systemic operation of the economy, and the disengagement of the real and financial spheres is highlighted. All of this is seen to be a consequence of a dynamic where investment is based on speculation and where growth is based not on production but on continuous debt (Gills 2010; Huerta and Maldonado 2011; Huang et al. 2012).

In the current climate, other topics converge with economics when the word crisis is mentioned, the following being examples of this: the environment (Park et al. 2008) with climate change (Archer and Rahmstorf 2010; Gilding 2011) or energy conflicts (Ozturk et al. 2013); citizens and their relationship with and control of public administration (Kriesi 2012; Burnham 2014); the influence of austerity policies and their impact on social welfare (Greve 2012; Navarro 2013; Jordà and Taylor 2013) or employment (Ravn and Sterk 2012; Rendahl 2012); and food production (Headey 2011, 2013), among others.

The year 2008 marks the beginning of the current crisis, which came about as a consequence of the lack of liquidity and solvency in the banking systems (Kotz 2009), and the excesses of the financial markets in the USA (Wagner 2010). These processes led to a deterioration in macroeconomic prospects and a fall in production in the main markets, and as a result had a decisive impact on the field under study in this paper: the tourist industry (Smeral 2009).

Over the last few years, tourism has seen a growing number of academic studies that focus on this particular topic (Cheng et al. 2011; Nunkoo et al. 2013), this providing new literature related to the influence of the crisis (Ritchie et al. 2010), with special attention being paid to risk management (Anderson 2006; Vles 2012), impact projections (Sausmarez 2013), recovery strategies (Prideaux and McNamara 2013; Paraskevas and Altinay 2013) and public safety (Hall 2010).

It can thus be seen that research journals play a very significant role in the development of this academic field (Van Doren et al. 1994; Xiao and Smith 2006). Tourism, as a scientific field, has paid special attention to the development of the classification of journals and the impact of their articles (Pechlaner et al. 2004; Hall 2005; McKercher 2005; Ryan 2005; Jamal et al. 2008; Hall 2011; Hung and Law 2011; Gursoy and Sandstrom 2014). In the measurement of these particular aspects, bibliometrics provides an especially useful tool (Gómez Caridad and Bordons 2009). The techniques most commonly used to classify journals (Gursoy and Sandstrom 2014) include the following: the citation index and the impact factor; acceptance rates; downloads; the use of panels of experts; and peer review.

This production of scientific material can be examined from three perspectives: from a micro level, to study individual researchers; from a meso level, which presents the situation of a journal or institution; and finally, a third perspective known as a meta level, which takes into account an entire field of knowledge. Most studies that analyse the content of tourism journals have focused on the micro or meso level that is to say on the productivity or output of the authors and research centres. Less frequent are studies that approach this content from a meta perspective (Cheng et al. 2011; Hall 2005, 2011).

This paper proposes the analysis of the scientific literature on crisis and tourism through the use of sources provided by the Institute for Scientific Information (ISI), included in the Thomson Reuters Web of Knowledge (WoK). The aim is to prove the consolidation of this field of research by designing a Thematic Level of the Field (TLF) that identifies and measures the constituent elements (the continuity, collaboration, visibility and impact of the field of study) and at the same time identifies any trends and changes in the idea of crisis in tourism studies. 


\section{Method}

\section{Data collection: studies included in the sample}

Even though many specialised databases currently exist (Hall 2011), it is important to highlight those produced by the ISI, because of their widespread use in bibliometrics, in particular those provided by the Social Sciences Citation Index (SSCI) in social sciences (1956-2013) and the Science Citation Index Expanded (SCI-Expanded) in experimental sciences (1900-2013). The main reasons for their extended use are the following: their multidisciplinary character, which allows all areas to be studied using only one database; the inclusion of information about the authors of the studies; and, fundamentally, the annual production of an internationally recognised Impact Factor (IF), provided by the Journal Citation Report (JCR) (Gómez Caridad and Bordons 2009; Pechlaner et al. 2004; Van Leeuwen 2006).

In order to carry out this study, the two databases that can be accessed through the Web of Science (WoS) have both been used, being provided by Thomson Reuters as part of the WoK and consulted in March 2014. The main reason for using both the SSCI and the SCI is that not all tourism articles can be registered with the SSCI, although a priori this is where the greatest number of tourism articles can be found (Ryan 2005).

The process used to obtain bibliographic citations consisted of analysing the information contained under the field TITLE when introducing the words tourism and crisis and connecting them with the conjunction and to show that they have to be introduced together.

The choice of the title as a search element was due to two main factors. First of all, the title introduces the article using a concise, precise, exact and useful combination of words, always carefully chosen by the author. Secondly, the title is used by archivists when storing, searching for and recovering information, that is to say for their archival work. These two factors make the title a key element for attracting the interest not only of editors and reviewers but also of potential readers. Both factors influenced the choice of the title as a search element above other parts of the article, such as the abstract or the key words. There have been no studies that focus on the importance of the title in the field of tourism, although in other fields, like the social sciences, there are significant references to its use as part of bibliometric analysis and its importance in classifying studies (Alcaraz-Ariza and Salager-Meyer 2012; Goodman 2000; Haggan 2004; Hartley 2007; Wang and Bai 2007).

For the purposes of distribution over time, the years 1956-2013 were introduced under the field TIMESPAN. This period corresponds to the total number of years available in the WoS for both the SSCI and the SCI databases.

The use of these first two filters delivered a total of 67 documents in diverse formats: article $(68.7 \%)$, book review $(22.4 \%)$, editorial material $(5.9 \%)$, correction $(1.5 \%)$ and meeting abstract $(1.5 \%)$.

The third filter involved limiting DOCUMENT TYPES to articles. The choosing of the article as the preferred document type was due it being the main tool for learning about the production, circulation and exchange of academic knowledge. This choice is justified by the use of the article in other studies in the field of bibliometrics (Yi and Jie 2011), and by its validity as a tool for classifying research. The article is currently considered to be the most relevant type of scientific document and is used to identify the relative importance of researchers, departments and institutions in a given field (Cheng et al. 2011; Hall 2005, 2011; Weiner 2001). 
With these three filters, a study sample of 46 articles was provided, of which $91.3 \%$ correspond to the SSCI and $8.7 \%$ to the SCI-Expanded.

For the treatment of the sample, the items in the database were saved as a TXT file, in order to subsequently be introduced into a bibliographic citation manager. After the items had been analysed, tables were created for subject categories, participating institutions, bibliographic citations, titles of journals, and so forth, in the form of spreadsheets. Finally, they were exported to a statistical database to be processed.

\section{Data analysis: tools for the measurement of variables}

The proposed measurement is carried out using certain values, with the aim of establishing continuity, visibility, the collaborative pattern and the impact of the field generated by studies related to tourism and crisis (Table 1).

This is how the different components of the TLF are developed:

- Temporal Continuity of the Field (TCF): Proximity measurements are used to evaluate the degree of similarity between intervals. Thus, the lower the value (relative to the first interval), the lower the degree of existing dissimilarity. To this end, the Euclidian distance (García et al. 2014; Sandoval et al. 2015) is applied.

Temporal continuity is important, and some authors classify it based on the achievement of results accumulated after specific time intervals (Hirsch 2007). The TCF will be established as the average of the distance between the oldest interval and the rest, relative to the last three 5-year periods (Borrett et al. 2014; Zitt and Small 2008). The greater the number of articles published in the last three 5-year periods, the greater the continuity. In this way, the interest in this field over time and its current importance can be clearly seen.

A cluster (aggregate) analysis is also applied with the aim of establishing the degree of homogeneity, based on the adopted values (Chen 2011a, b). The grouping method used in the developed clusters involves finding links between groups and within the cluster we can observe which groups are closest to each other.

- Contribution to the Visibility of the Field (CVF): In this analysis the relationship between the source of the citation and the article cited is established (Blagus et al. 2015). The interest here comes from the fact that the citations reflect the influence of the article in the scientific community and measure the interest in a journal (Jogaratnam et al. 2005; Zhao and Ritchie 2007; Jamal et al. 2008; Hall 2011). The continuity of the

Table 1 Indicator of thematic-level measurement

\begin{tabular}{|c|c|c|}
\hline Core & Subcore & References \\
\hline \multirow[t]{4}{*}{$\begin{array}{l}\text { Thematic Level of } \\
\text { the Field (TLF) }\end{array}$} & $\begin{array}{l}\text { Temporal Continuity of the } \\
\text { Field (TCF) }\end{array}$ & $\begin{array}{l}\text { Borrett et al. (2014), Hirsch (2007), Zitt and Small } \\
\text { (2008) }\end{array}$ \\
\hline & $\begin{array}{l}\text { Contribution to the } \\
\text { Visibility of the Field } \\
\text { (CVF) }\end{array}$ & $\begin{array}{l}\text { Blagus et al. (2015), Costas and Bordons (2007), } \\
\text { Hirsch (2007), Waltman and Van Eck (2012) }\end{array}$ \\
\hline & $\begin{array}{l}\text { Patterns of Collaboration in } \\
\text { the Field (PCF) }\end{array}$ & $\begin{array}{l}\text { Ding (2011), Hoekman et al. (2010), Koseoglu } \\
\text { (2016), Lee et al. (2011), Newman (2001) }\end{array}$ \\
\hline & $\begin{array}{l}\text { Evolution of the Impact } \\
\text { Factor of the Field (EIFF) }\end{array}$ & Larivière and Gingras (2010), Seglen (1997) \\
\hline
\end{tabular}


citation is a common bibliometric point of reference, expressed through different indexes. An example is the h-index (Costas and Bordons 2007; Hirsch 2007; Waltman and Van Eck 2012), the basis of a great many studies and disciplines, among which can be found geographical science or tourism itself (Hall 2011; Lasanta Martínez and García Ruiz 2013).

The grouping of the four intervals for the CVF is based on the following criteria relative to a given article: no citations $(c=0)$, only one citation $(c=1)$, more than one citation but with no continuity, so not cited every year after publication $\left(c>1_{\# \neq \&}\right)$, and finally more than one citation and with continuity, so cited every year after publication $\left(c>1_{\#=\&}\right.$ ). The citations used belong to the WoS Core Collection (SCI and SSCI).

The CVF will be established as the influence on scientific knowledge, and to this end the accumulated value of the continuous and non-continuous citations is standardised. A dendogramme representing the visibility of the authors cited in the sample (Ma and Liu 2011) is also included.

- Patterns of Collaboration in the Field (PCF): The publications are used to extract information relative to the collaboration among authors, institutions or countries, with the aim of establishing the degree of cooperation involved in the production of research results (Abbasi and Altmann 2010; Newman 2001; Hoekman et al. 2010; Racherla and $\mathrm{Hu} 2010)$. The distribution by intervals establishes the percentages of articles involving zero collaboration (ZC), national collaboration (NC) with more than one author from the same or different institutions in the same country, and international collaboration (IC) with authors from institutions in at least two different countries.

The PCF will establish the existence of articles produced in collaboration at both a national and an international level. To this end, the accumulated value of both types of collaboration has been standardised as 0.75 for IC and as 0.25 for NC, with the impact of the international collaboration involved in the resulting publications thus being highlighted (Ding 2011; Koseoglu 2016; Lee et al. 2011; Racherla and Hu 2010).

- Evolution of the Impact Factor of the Field (EIFF): The IF, which was first mentioned in 1955 by Garfield and introduced in 1963 by Garfield and Sher, has been the primary focus of many analyses of journal collection management, through the measurement of quality parameters for articles in particular and scientific publications in general. The IF is a concept that is widely dealt with in bibliometric studies, both in tourism and in other fields (Chang and Mcaleer 2012; Hall 2011; Yi and Jie 2011). The IF is one of the most commonly used scientometric indicators, in particular for the purpose of measuring quality (Garfield 2006; Hoeffel 1998). Some authors argue that publication in a high-impact journal increases the impact of an article (Larivière and Gingras 2010; Seglen 1997).

The distribution for the EIFF is based on the IF of the Thomson Reuters JCR quartiles of the journals, according to the year of publication of the article in the sample. Only the SSCI database has been used for this subcore value, since the other elements taken from the SCI-Expanded sample were published before 1997 and there is only one article from after this date, with the article in question not having had any continuous impact. The journals have been organised hierarchically by quartiles $(Q)$, according to the place that they occupy relative to the IF in JCR 2013 for SSCI $\left(Q_{\mathrm{SSCI}}\right)$, and for the sample $\left(Q_{\mathrm{s}}\right)$. Thus when the result of the differences is equal to 0 , it corresponds to a standard of 0.5 in the EIFF. Everything in this standard that is over the WoS standard is added to 0.5 and everything that does not reach it is subtracted from this value. 
The proposal finishes with the generation of the TLF.

$$
\begin{aligned}
\mathrm{TLF}= & \overbrace{\sum_{i=\text { no continuity }}^{\text {continuity }} f_{i}}^{\mathrm{CVF}} * 0.20+\overbrace{\sum_{i=1}^{3} \frac{\left(X_{i}-Y_{i}\right)^{2}}{3}}^{\mathrm{TCF}} * 0.20 \\
& +\overbrace{\left(0.75 * f_{\mathrm{IC}}+0.25 * f_{\mathrm{NC}}\right)}^{\mathrm{PCF}} * 0.20+\overbrace{\left(Q_{\mathrm{SSCI}}-Q_{\mathrm{m}}\right)}^{\mathrm{EIFF}} * 0.40
\end{aligned}
$$

The TLF is an attempt to describe the complexity of the normalisation process for bibliometric indicators in the use of the SSCI and the SCI-Expanded. The formula is made up of the four subcore values (CTT, CVT, PCT and EFIT), the first three being evenly weighted with 0.20 for each subcore value, and 0.40 being applied to the EFIT.

For the EFIT value there is a monitoring of its effect on the publications (Larivière and Gingras 2010), of the portrayal of the Life Cycle Product/Process Design (LCPD) (Seppälä and Hämäläinen 2001) and of the parameters of indicators associated with the Weighted Impact of Publications (WIP) and the Relative Contribution Score (RCS) (Vinkler 1988). This degree of monitoring is due to the EFIT being the most relevant subcore value in bibliometric classification (Habibzadeh and Yadollahie 2008). The value of the TLF is similar to other ratios such as the expected citation rate of the Centre for Science and Technology Studies at Leiden University (CWTS) (Moed 1996).

The TLF is evaluated using four categories according to the result obtained. Depending on their position, the values are represented on a standardised scale going from 0 to 1 . Additionally, a label has been included for each category in the form of a value-word (Table 2), in order to be able to express the results at a lexical level (Galindo-Pérez-deAzpillaga et al. 2014). These value-words are derived from the LCPD, where they are used as a forecast tool (Aguilar et al. 2012).

The first phase of Initial Dissemination refers to the beginnings of the field, when everything is still new and lacks endorsement. The field is recognised for its novelty and may awaken in researchers sufficient enthusiasm for them to begin to participate in its development.

Subsequently, there are two phases of expansion, the first of these being expressed by the term Early Growth, when apart from studies being steadily accumulated, the norms and guidelines that give shape to the field, which is by now developing rapidly, are laid down and gradually modified. During this phase an opening up of the scientific field takes place through the appearance of more authors.

This is followed by a phase of Later Growth, during which the norms and guidelines established previously continue to develop. The articles are highly regarded and the quality of the research is a differentiating factor.

Table 2 Standardisation of the indicators

\begin{tabular}{ll}
\hline $\begin{array}{l}\text { Standard of the } \\
\text { indicator }\end{array}$ & Value-word \\
\hline$[0-0.25)$ & Initial dissemination \\
{$[0.25-0.5)$} & Early growth \\
{$[0.5-0.75)$} & Later growth \\
{$[0.75-1]$} & Consolidated impact
\end{tabular}


Finally, the field can maintain its momentum or become less prominent. In the phase of Consolidated Impact, its positioning in the world of scientific research and the existence of a TLF indicator are established. The field has reached the age of maturity in its life cycle.

For the time frame of the TCF, CVF and PCF indicators, the information has been classified in groups at various intervals, including the last three 5-year periods (Zitt and Small 2008) leading up to 2013 (2009-2013; 2004-2008; 1999-2003), with the aim of analysing the current situation of the field. There remains a longer interval (1956-1998), which includes those earlier publications that may be considered pioneers in the field. The division into 5-year periods is frequently used as the basis for bibliometric studies, both in tourism and in other fields, and is also used recurrently for categorisation in the establishment of accumulated impact (Albacete-Sáez et al. 2013; Granda-Orive et al. 2011; Iñigo and Chaves 2012).

The entire period of publication of the JCR (1997-2013) has only been drawn upon for the EIFF subcore value.

\section{Results}

\section{Temporal Continuity of the Field (TCF)}

With the TCF can be established the distance that exists between the last three 5-year periods for articles on crisis and tourism published from 1956 to 2013, with the aim of measuring the degree of consolidation of this field. An analysis is carried out that is classified according to the four specified intervals, with articles being placed in groups of 5 -year periods, this reinforcing the concept of continuity. This analysis proves that the intervals remain constant in 5-year periods and not year by year.

In the first interval, from 1956 to 1998, the scientific articles in this field are limited in number. On the one hand, there are those that propose a planning framework for the management of crisis situations in general (Arbel and Bargur 1980). On the other hand, there are those that focus on specific case studies: on the effects of tourism in the Himalayas (Forsyth 1991), the differences between the response strategies of tourist organisations in the USA and those in Spain (González-Herrero and Pratt 1998a), or how the effects of touristification in Prague can generate tensions that lead to a crisis of political legitimisation in the Czech Republic (Cooper and Morpeth 1998).

It is in the second interval, from 1999 to 2003, that conceptual and methodological articles are developed, dealing with the strategic focus that is employed when faced with situations that include the following: political, economic and health-related situations (Stafford 2003), the political and economic crises in Asia from 1997 (Prideaux et al. 2003), and the attack that took place on the 11th September, 2001 (Blake and Sinclair 2003).

In the period comprising the years from 2004 to 2008, studies with a strategic focus continue to be produced (Ritchie 2004), based on areas such as the following: the consequences of the Gulf War of 1991 (Yarcan 2007), the collapse of the insurance company $\mathrm{HIH}$ and the disappearance of Ansett Airlines in 2001 (Anderson 2006), and the outbreaks of severe acute respiratory syndrome (SARS) in 2003 (Wan 2008).

The final interval is from 2009 to 2013. According to data from the United Nations World Tourism Organization (UNWTO 2009), international tourism declined as from the second half of 2008. In spite of its vulnerability, international tourism has shown itself to be more resilient and more able to recover than other economic sectors that can be seen to be weaker in the face of the current crisis. The crisis in tourism has been a subject of 


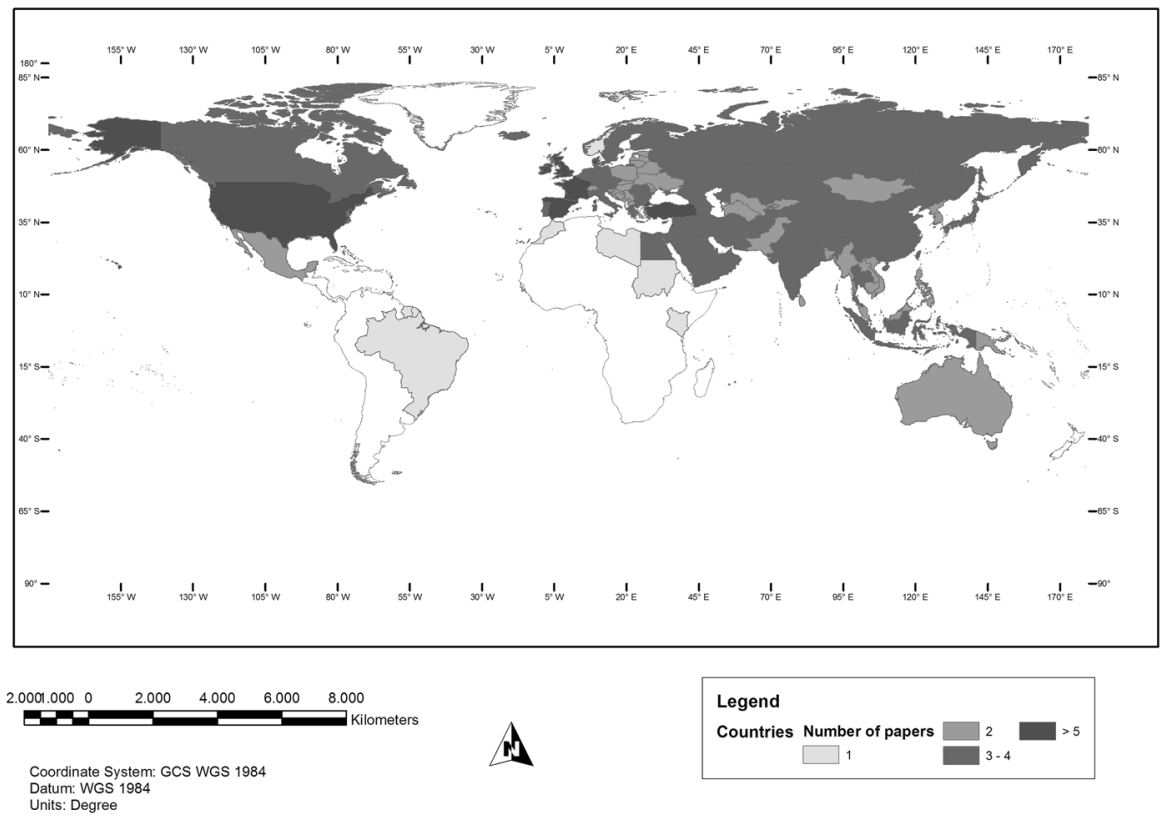

Fig. 1 Study area of the articles in the sample

Table 3 Matrix of proximity and standardisation of the euclidian distance of the TCF

\begin{tabular}{lllll}
\hline TCF & $1956-1998$ & $1999-2003$ & $2004-2008$ & $2009-2013$ \\
\hline $1956-1998$ & 0.000 & 0.000 & 0.071 & 0.991 \\
$1999-2003$ & 0.000 & 0.000 & 0.080 & 1.000 \\
$2004-2008$ & 0.071 & 0.080 & 0.000 & 0.858 \\
$2009-2013$ & 0.991 & 1.000 & 0.858 & 0.000 \\
\hline
\end{tabular}

The non-standardised table is included in "Appendix 1"

academic analysis since 2009, and in general terms economic and financial crises have always been of great interest to researchers (Hall 2010; Smeral 2010; Papatheodorou et al. 2010; Chen 2011a, b; Racherla and Hu 2009; Wergin 2012).

These crises have gone hand in hand with the following major areas (Fig. 1): Asia (Song and Lin 2010; Li et al. 2010; Cohen and Neal 2010; Rittichainuwat 2013; Muenster and Muenster 2012; Paraskevas et al. 2013), both North and South America (Ritchie et al. 2010; Pennington-Gray et al. 2011; Connell 2013), Europe (Lazar and Lazar 2009; Johannesson and Huijbens 2010; Cojocariu 2010; Page et al. 2012; O'Brien 2012; Boukas and Ziakas 2013) and even the Middle East (Jallat and Shultz 2011; Motahedin 2012; Avraham 2013; Morakabati 2013). All these articles contribute to a better understanding of the changes and trends that have that have taken place in scientific writing (Wang 2009).

The concept of the crisis and its global impact encompasses changes in the following consumer circumstances: the threat of unemployment (Alegre et al. 2013), loss of income, and uncertainty in the assessment of both investment (Smeral 2009) and education (LilloBanuls and Casado-Díaz 2012). 
With the proximity matrix (Table 3), it can be seen how the greatest number of articles is produced during the fourth interval, 2009-2013. It is, in fact, a dissimilarity matrix.

The distance from the first to the fourth interval is considerable (0.991), and it is here that the surge of the field takes place. There is also a distance between the first and the third interval, although it is almost insignificant (0.071), and there is no distance at all between the first and the second interval.

\section{Contribution to the Visibility of the Field (CVF)}

The 46 articles were cited on 478 occasions, with a citation rate per element of 10.39 and an h-index of 12. Of the articles received, $41.30 \%$ were not cited at all, although it has to be said that most of these were published in the last period. On the other hand, $58.70 \%$ of the articles were cited: $4.38 \%$ were cited once, $19.55 \%$ more than once but not every year, and $34.77 \%$ every year as from the year of publication (Table 4). These results show the interest in and the contemporary nature of the field.

The following citations represent the visibility of the authors who appear most frequently in the sample (Fig. 2).

In the cluster that refers to the visibility of the articles, the group of articles that stands out most is that made up of Ritchie (2004), Blake and Sinclair (2003) and Prideaux et al. (2003), which thus become the main bibliographical points of reference. The three articles are cited frequently within the sample as a whole. Three other articles that can be placed together are Hall (2010), Smeral (2010) and Papatheodorou et al. (2010). In this case, the articles are those that cite other articles from the sample most frequently rather than being cited themselves. In the case of Hall, this is mainly due to the fact that the article is a bibliographical compilation of the field of study. Another significant grouping is that composed of Okumus et al. (2005), González-Herrero and Pratt (1998b), Chen (2011a, b), Song and Lin (2010) and Wang (2009), these articles being frequently cited by other articles from the sample.

\section{Patterns of Collaboration in the Field (PCF)}

The articles included in the sample were written by 83 authors and the rate of co-authorship is 1.8 authors per study. Individual studies involving zero collaboration (ZC) correspond to $45.65 \%$ of the articles in the sample, this percentage being considered by some authors (Sydserff and Weetman 2002) to be a transitivity index (Table 5). All the other articles depend on teamwork, because of which the degree of collaboration is labelled as mediumhigh. This percentage has varied over the years and according to the precise field under study. The higher the number of authors per article, the lower the percentage: two authors per article $(35 \%)$, three authors $(15 \%)$, four authors $(2 \%)$ and five $(2 \%)$.

Table 4 Distribution of the CVF by period

\begin{tabular}{llllrrr}
\hline CVT & $1956-1998$ & $1999-2003$ & $2004-2008$ & $2009-2013$ & Total & $\%$ \\
\hline$c=0$ & 1 & 1 & 0 & 17 & 19 & 41.30 \\
$c=1$ & 0 & 0 & 1 & 1 & 2 & 04.38 \\
$c>1_{\# \neq \&}$ & 4 & 0 & 2 & 12 & 9 & 19.55 \\
$c>1_{\#=\&}$ & 0 & 2 & 2 & 16 & 34.77 \\
\hline
\end{tabular}




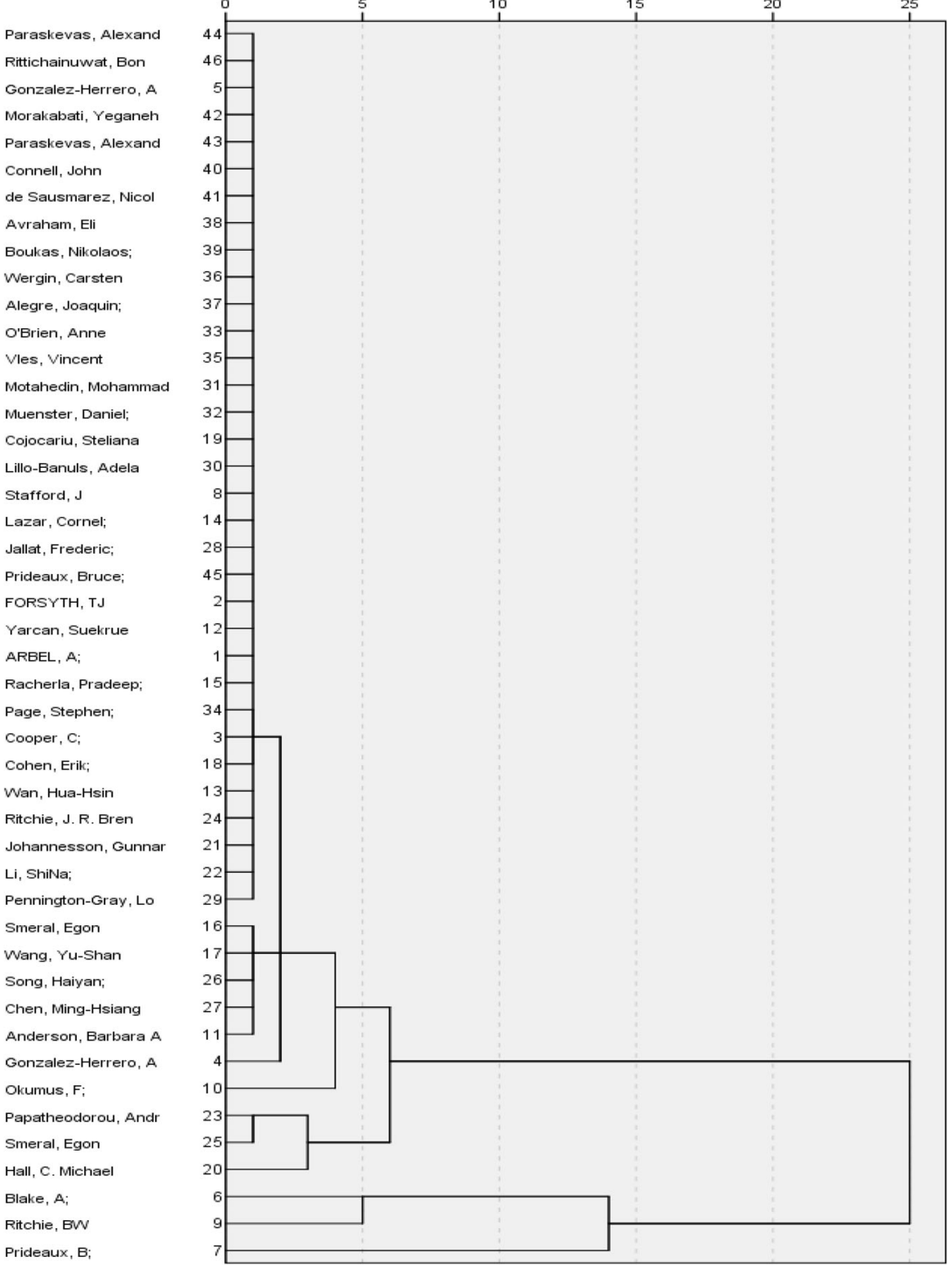

Fig. 2 Authors with more than one citation. Note Dendogramme that uses an average correlation (between groups), rescaled distance cluster combination

At the same time, the rate of institutional co-authorship is 2.44 authors from the same institution per article. This figure rises if the authors carry out research in the same country (2.53 authors per article). NC accounts for $32.61 \%$ of the articles, and the institutions involved are mainly in the UK, the USA and Spain.

Collaboration with authors working in other countries, that is to say the degree of internationalisation (IC) of the articles in the sample is medium (21.74 \%) (Fig. 3). There 
Table 5 Distribution of the PCF by period

\begin{tabular}{llllll}
\hline PCF & $1956-1998$ & $1999-2003$ & $2004-2008$ & $2009-2013$ & $\%$ \\
\hline Zero collaboration (ZC) & 1 & 1 & 4 & 15 & 45.65 \\
National collaboration (NC) & 1 & 1 & 1 & 12 & 32.61 \\
International collaboration (IC) & 3 & 1 & 0 & 6 & 21.74 \\
\hline
\end{tabular}
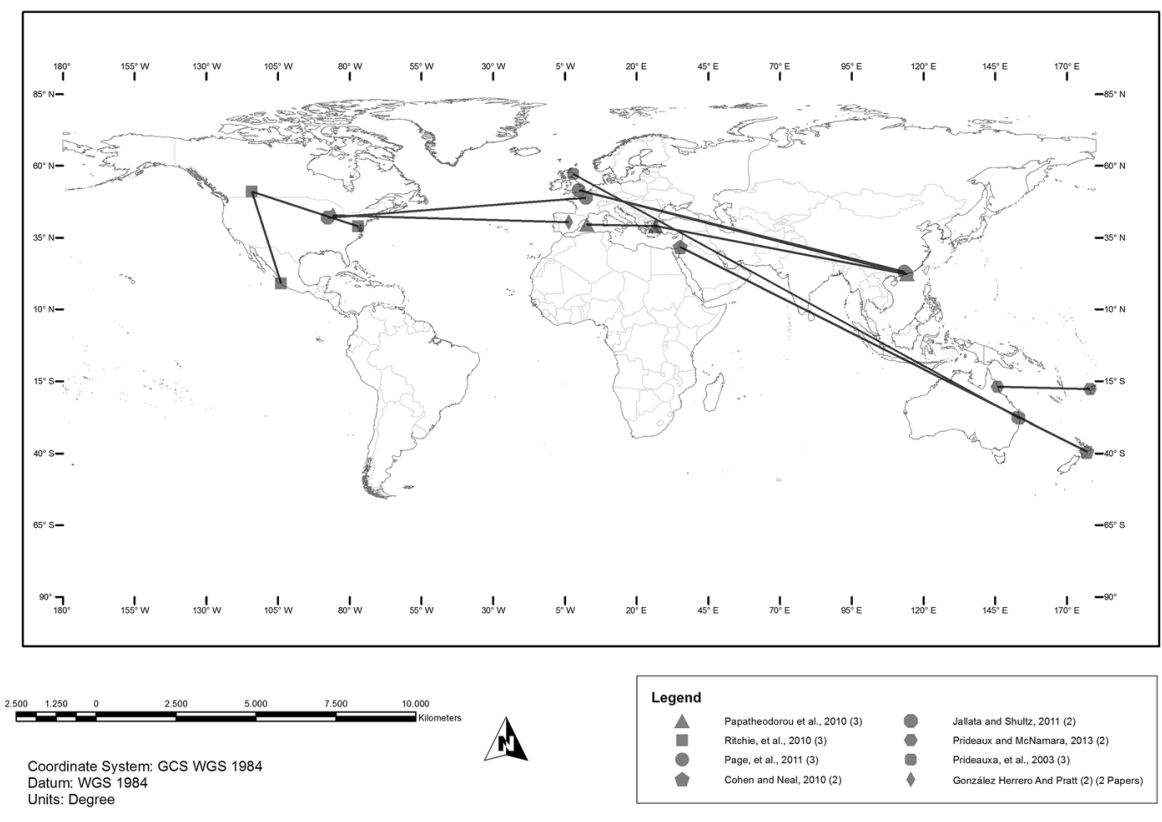

Fig. 3 International collaboration in the sample

exist marked differences between the patterns found in American and British universities, where national collaboration predominates, and the other European, the Asian and the Australasian universities, which are more oriented towards international collaboration.

In general, collaboration depends on how open the scientific community is to participating in research projects together with fellow researchers from the same or another country or speciality. International collaboration is currently one of the central characteristics of scientific activity and confirms both the importance of interdisciplinary research and the formal and informal exchange of knowledge among the members of the academic community.

\section{Evolution of the Impact Factor of the Field (EIFF)}

The articles that comprise the scientific production included in this study for the period 1956-2013 were published in 23 scientific journals ("Appendices 2, 3") from 12 publishers. In most cases, these publishers are the most prestigious according to the SPI (Scholarly Publishers Indicators) (Giménez-Toledo et al. 2013). In the sample the following are represented: Elsevier (26\%), Sage (17.5\%), Taylor and Francis $(8.5 \%)$, Wiley $(8.5 \%)$ and Blackwell $(8.5 \%)$. 
Table 6 Distribution of the EIFF

\begin{tabular}{llll}
\hline Quartiles & $Q_{\text {SSCI }}$ & $Q_{\mathrm{s}}$ & $Q_{\mathrm{s}}-Q_{\text {SSCI }}$ \\
\hline Q3 & 0.434 & 0.516 & 0.082 \\
Q2 & 0.871 & 0.878 & 0.007 \\
Q1 & 1.531 & 1.559 & 0.028 \\
& & & 0.117 \\
\hline
\end{tabular}

There are five journals that have published the most articles related to tourism and crisis, the most significant being Tourism Management. Of all the articles in the study sample, $17.4 \%$ were published in this journal, which is followed by a group of four journals that together published $37 \%$ of the articles: Journal of Travel Research, Current Issues in Tourism, Annals of Tourism Research and International Journal of Tourism Research.

The results show that the leading indexed journals have remained relatively consistent in this respect over the years. The greatest proportion of articles about crisis and tourism are published in journals from the first quartile $(61 \%)$, followed by those from the second quartile $(17 \%)$, with those from the third and fourth quartiles being less representative ( 9 and $13 \%$ respectively) (Table 6).

The chosen sample is similar to the four quartiles of the SSCI together, and in Q1, Q2 and Q3 the sample has even higher values. The values that have grown the least are those that are in Q2, with a difference of 0.007. The highest values are found in Q3 with 0.082 . The total value of $Q_{\mathrm{s}}$ relative to $Q_{\mathrm{SSCI}}$ is 0.117 .

\section{The Thematic Level of the Field (TLF)}

Bibliometric indicators, used appropriately and in combination with other indicators, provide a valuable tool for the evaluation of scientific activity. The TLF helps to establish the degree of Consolidated Impact of the field by studying the relevant publications. The results are presented in Table 7 , which respects both the methodological design and the weighting factor of the TLF.

On the one hand, through the activity indicators the continuity of the published articles (TCF) has been presented. The studies on crisis and tourism are almost non-existent in the first periods and the boom corresponds exclusively to the last 5-year period, in which a considerable jump (0.991) is made. The average distance, between the oldest interval and the other three, that is to say relative to the last 15 years, is 0.354 over 1 . The development of the field has taken place recently and has not yet been consolidated; it requires stability and continuity over time. In the articles studied it can be seen that the crisis has not only affected the financial sector, but has also reached the production sectors and the global economy as a whole. The TCF is in a phase of Early Growth.

Two of the other parts of the indicator that have been analysed are those related to impact. In this case, both the contribution to the CVF and the position that has been normalised through quartiles (EIFF) have been included. The final value of CVF is 0.543 over 1 , composed of the accumulated value of $c>1_{\#=\&}$ and $c>1_{\# \neq \& \text {. The value cor- }}$ responding to EIFF is 0.617 over 1 , by applying the summation of the differences between the quartiles to the standard 0.5 , since these differences are already situated with a value higher than $Q_{\mathrm{SSCI}}$. Both values (CVF and EIFF) are the result of a high level of interdisciplinary research that takes place as part of the process of integration of different branches of the field of study. It is possible that other disciplines are used as a starting 
Table 7 Results of the TLF

\begin{tabular}{llllll}
\hline & TCF & CVF & PCF & EIFF & TLF \\
\hline Results without weighting & 0.354 & 0.543 & 0.543 & 0.617 & Later growth \\
Value-words & Early growth & Later growth & Later growth & Later growth & \\
Weighting factors & 0.2 & 0.2 & 0.2 & 0.4 & 0.535 \\
Results of the subcore values & 0.071 & 0.109 & 0.109 & 0.247 & \\
\hline
\end{tabular}

point, but that they lose their individuality and exchange information with the field of tourism, giving rise to new methods, models and structures. A phase of Later Growth is achieved for the CVF, but the most prominent result of all is achieved for the EIFF. What is confirmed is that articles about crisis and tourism are of interest to publications with notable impact.

Then, there are the collaboration indicators (PCF). Their final value is 0.543 over 1 . In recent decades, co-authorship in scientific articles has grown. Some of the reasons for this are the following: a high degree of specialisation, with the creation of specialist research teams; multidisciplinary collaboration for the solving of scientific problems; and the sharing of available resources. The PCF is in a phase of Later Growth.

Finally, the TLF, with 0.535 over 1, is labelled with Later Growth in the field of crisis and tourism. This growth is characterised by studies that, as has been confirmed, cover both the theoretical and the practical sides of the field, and they constitute a challenge within the framework of tourism as a discipline. The difference that must be made up to reach Consolidated Impact is 0.215 . In order to achieve this, future articles must be written from different perspectives that refer to changes and trends in the uncertainty surrounding areas such as economic activity, the welfare of the population, climate change and natural disasters.

The TLF, following the pattern previously established, can continue to help consolidate this field's position in the scientific community (in terms of continuity, visibility, collaboration and impact) by maintaining its methodological contribution as a differentiating factor, without which it will shrink and not reach maturity in its life cycle.

\section{Conclusions}

Tourism companies and destinations currently find themselves in a complex market in which in order to be successful they have to develop innovative ideas, which involve promoting heritage, getting their brand to stand out, encouraging social participation, ensuring customer loyalty, and sharing resources through the phenomenon of the collaborative economy. It is in this sense that being able to determine the current state of the scientific literature that conceptually combines tourism and crisis reinforces the bibliometric effort presented in this article.

The scientific beginning of a new field is a slow process, and distrust of the first results is enormous, due mainly to the weakness of the initial methodological procedures and the still insubstantial nature of its theoretical constructs. Nevertheless, the results of this article show that research into tourism and crisis is more solid than it was 15 years ago. The researchers in question are now more competitive and better equipped to deal with the challenges provided by the most prestigious journals. The proposed objective has been 
achieved, since the TLF has been successfully designed and explained for the purpose of proving the consolidation of the field.

The current use of bibliometrics as a measurement tool is due, in part, to the proliferation and availability of digital information sources and resources. With technological progress, it is now possible to access computerised sources and handle large volumes of data. Digital information is the gold of the 21 st century, although its normalisation should not be seen as part of a generic need to formulate general rules to be applied in all fields. Normalisation can only be achieved from the point of view of applying the appropriate methodologies in relation to the field of research in which it is to be implemented (Moed 1996).

The method used can be applied to other concepts that can be found in the different phases, from the initial phase to consolidation, including the following: tourism and sustainability; tourism, social capital and governance; tourism and the effects of social networks; tourism and resilience; tourism and safety; and tourism and diasporas. There is a need to foster the future development of norms in bibliometrics based on the exchange of experiences and the sharing of knowledge in the framework of tourism as a scientific discipline.

\section{Appendix 1: Temporal Continuity of the Field (TCF)}

See Fig. 4 and Tables 8 and 9.

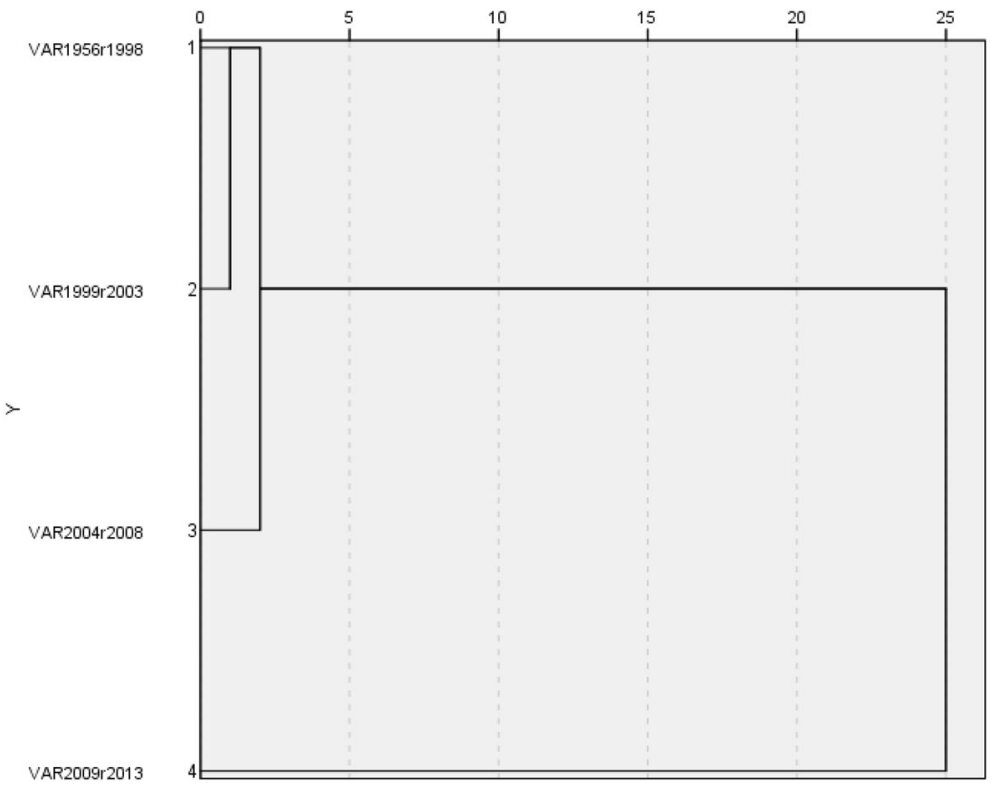

Fig. 4 Dendogramme representing the average correlation between periods. Note Dendogramme that uses an average correlation (between groups). Rescaled distance cluster combination 
Table 8 Matrix of proximity to the non-standardised euclidian distance

This is a dissimilarity matrix

\begin{tabular}{lcccc}
\hline & \multicolumn{4}{l}{ Euclidian distance from the squared number } \\
\cline { 2 - 5 } & $1956-1998$ & $1999-2003$ & $2004-2008$ & $2009-2013$ \\
\hline $1956-1998$ & 0.000 & 5.000 & 13.000 & 117.000 \\
$1999-2003$ & 5.000 & 0.000 & 14.000 & 118.000 \\
$2004-2008$ & 13.000 & 14.000 & 0.000 & 102.000 \\
$2009-2013$ & 117.000 & 118.000 & 102.000 & 0.000 \\
\hline
\end{tabular}

Table 9 History of the conglomeration

\begin{tabular}{|c|c|c|c|c|c|c|}
\hline \multirow[t]{2}{*}{ Stage } & \multicolumn{2}{|c|}{ Combined cluster } & \multirow[t]{2}{*}{ Coefficients } & \multicolumn{2}{|c|}{ First appearance of the stage cluster } & \multirow{2}{*}{$\begin{array}{l}\text { Following } \\
\text { stage }\end{array}$} \\
\hline & Cluster 1 & Cluster 2 & & Cluster 1 & Cluster 2 & \\
\hline 1 & 1 & 2 & 5.000 & 0 & 0 & 2 \\
\hline 2 & 1 & 3 & 13.500 & 1 & 0 & 3 \\
\hline 3 & 1 & 4 & 112.333 & 2 & 0 & 0 \\
\hline
\end{tabular}

\section{Appendix 2: Journals by number of articles, publisher and country of publisher}

\begin{tabular}{|c|c|c|c|}
\hline Journal & Articles & Publisher & $\begin{array}{l}\text { Country of } \\
\text { publisher }\end{array}$ \\
\hline Tourism Management & 8 & Elsevier & $\begin{array}{l}\text { United } \\
\text { Kingdom }\end{array}$ \\
\hline Journal of Travel Research & 6 & Sage & United States \\
\hline Current Issues in Tourism & 5 & Taylor and Francis & $\begin{array}{l}\text { United } \\
\text { Kingdom }\end{array}$ \\
\hline Annals of Tourism Research & 3 & Elsevier & United States \\
\hline International Journal of Tourism Research & 3 & Wiley & $\begin{array}{l}\text { United } \\
\text { Kingdom }\end{array}$ \\
\hline Cornell Hospitality Quarterly & 2 & Sage & United States \\
\hline Island Studies Journal & 2 & $\begin{array}{l}\text { University of Prince } \\
\text { Edward Island }\end{array}$ & Canada \\
\hline Metalurgia International & 2 & Editura Stiintifica & Romania \\
\hline American Behavioral Scientist & 1 & Sage & United States \\
\hline Development and Change & 1 & Blackwell & $\begin{array}{l}\text { United } \\
\text { Kingdom }\end{array}$ \\
\hline European Journal of Operational Research & 1 & Elsevier & Netherlands \\
\hline Global Ecology and Biogeography Letters & 1 & Wiley & $\begin{array}{l}\text { United } \\
\text { Kingdom }\end{array}$ \\
\hline International Journal of Hospitality Management & 1 & Elsevier & $\begin{array}{l}\text { United } \\
\text { Kingdom }\end{array}$ \\
\hline Journal of Communication & 1 & Blackwell & $\begin{array}{l}\text { United } \\
\text { Kingdom }\end{array}$ \\
\hline
\end{tabular}




\begin{tabular}{|c|c|c|c|}
\hline Journal & Articles & Publisher & $\begin{array}{l}\text { Country of } \\
\text { publisher }\end{array}$ \\
\hline Journal of World Business & 1 & Elsevier & United States \\
\hline $\begin{array}{l}\text { Life Science Journal-Acta Zhengzhou University } \\
\text { Overseas Edition }\end{array}$ & 1 & Marsland Press & China \\
\hline Loisir et Société/Society and Leisure & 1 & Taylor and Francis & Canada \\
\hline Middle Eastern Studies & 1 & Routledge & $\begin{array}{l}\text { United } \\
\text { Kingdom }\end{array}$ \\
\hline Psychological Reports & 1 & Ammons Scientific & United States \\
\hline Public Relations Review & 1 & Elsevier & Netherlands \\
\hline $\begin{array}{l}\text { Revue de Géographie Alpine/Journal of Alpine } \\
\text { Research }\end{array}$ & 1 & Armand Colin Paris & France \\
\hline Tourism Economics & 1 & Ip Publishing & $\begin{array}{l}\text { United } \\
\text { Kingdom }\end{array}$ \\
\hline Urban Studies & 1 & Sage & $\begin{array}{l}\text { United } \\
\text { Kingdom }\end{array}$ \\
\hline
\end{tabular}

\section{Appendix 3: Impact Factor of the Field (EIFF)}

See Fig. 5.

AMERICAN BEHAVIORAL SCIENTIST
PUBLIC RELATIONS REVIEW
TOURISM ECONOMICS
INTERNATIONAL JOURNAL OF TOURISM RESEARCH
CORNELL HOSPITALITY QUARTERLY
CURRENT ISSUES IN TOURISM
METALURGIA INTERNATIONAL
MIDDLE EASTERN STUDIES
PSYCHOLOGICAL REPORTS
DEVELOPMENT AND CHANGE
URBAN STUDIES
INTERNATIONAL JOURNAL OF HOSPITALITY
MANAGEMENT
JOURNAL OF TRAVEL RESEARCH
JOURNAL OF COMMUNICATION
JOURNAL OF WORLD BUSINESS
EUROPEAN JOURNAL OF OPERATIONAL RESEARCH
TOURISM MANAGEMENT
ANNALS OF TOURISM RESEARCH
GLOBAL ECOLOGY AND BIOGEOGRAPHY (LETTERS)

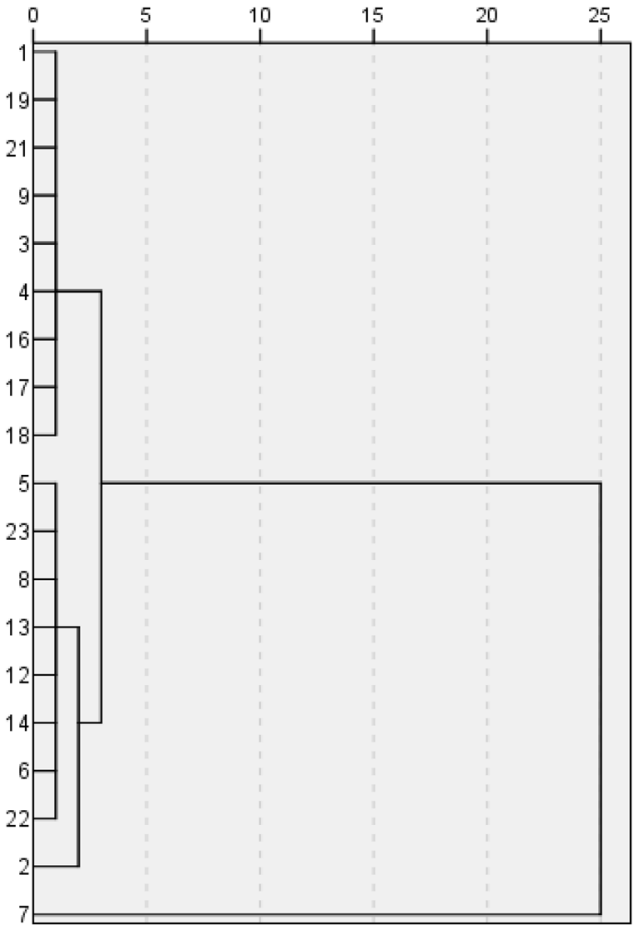

Fig. 5 Dendogramme of the historical impact factor of the journals in the sample. Note Dendogramme that uses an average correlation (between groups), rescaled distance cluster combination 


\section{References}

Abbasi, A., \& Altmann, J. (2010). A social network system for analyzing publication activities of researchers. TEMEP discussion paper, South Korea, Seoul National University.

Aguilar, S., Ávalos, A. F., Giraldo, D. P., Quintero, S., Zartha, J. W., \& Cortés, F. B. (2012). La Curva en S como Herramienta para la Medición de los Ciclos de Vida de Productos. Journal of Technology Management and Innovation, 7(1), 238-248. doi:10.4067/S0718-27242012000100016.

Albacete-Sáez, C. A., Fuentes-Fuentes, M. M., \& Haro-Domínguez, M. C. (2013). La investigación española en turismo con impacto internacional (1997-2011). Una perspectiva desde la economía y la dirección de la empresa. Cuadernos de Economía y Dirección de la Empresa, 16(1), 17-28. doi:10.1016/j.cede. 2012.05.003.

Alcaraz-Ariza, M. Á., \& Salager-Meyer, F. (2012). Análisis contrastivos de los títulos en los artículos de investigación de neurología redactados en español e inglés. LSP Journal, 3(2), 27-50.

Alegre, J., Mateo, S., \& Pou, L. (2013). Tourism participation and expenditure by Spanish households: The effects of the economic crisis and unemployment. Tourism Management, 39, 37-49. doi:10.1016/j. tourman.2013.04.002.

Anderson, B. A. (2006). Crisis management in the Australian tourism industry: Preparedness, personnel and postscript. Tourism Management, 27(6), 1290-1297. doi:10.1016/j.tourman.2005.06.007.

Arbel, A., \& Bargur, J. (1980). A planning-model for crisis management in the tourism sector. European Journal of Operational Research, 5(2), 77-85. doi:10.1016/0377-2217(80)90205-2.

Archer, D., \& Rahmstorf, S. (2010). The climate crisis: An introductory to climate change. Cambridge: Cambridge University Press.

Avraham, E. (2013). Crisis communication, image restoration, and battling stereotypes of terror and wars: Media strategies for attracting tourism to Middle Eastern Countries. American Behavioral Scientist, 57(9), 1350-1367. doi:10.1177/0002764213487733.

Blagus, R., Leskosek, B. L., \& Stare, J. (2015). Comparison of bibliometric measures for assessing relative importance of researchers. Scientrometrics, 105(3), 1743-1762. doi:10.1007/s11192-015-1622-6).

Blake, A., \& Sinclair, M. T. (2003). Tourism crisis management: US response to September 11. Annals of Tourism Research, 30(4), 813-832. doi:10.1016/S0160-7383(03)00056-2.

Borrett, S. R., Moody, J., \& Edelmann, A. (2014). The rise of network ecology: Maps of the topic diversity and scientific collaboration. Ecological Modelling, 293, 111-127. doi:10.1016/j.ecolmodel.2014.02. 019.

Boukas, N., \& Ziakas, V. (2013). Impacts of the global economic crisis on Cyprus tourism and policy responses. International Journal of Tourism Research, 15(4), 329-345. doi:10.1002/jtr.1878.

Burnham, P. (2014). Depoliticisation: Economic crisis and political management. Policy and Politics, 42(2), 189-206.

Chang, C. L., \& McAleer, M. (2012). Citations and impact of ISI tourism and hospitality journals. Tourism Management Perspectives, 1, 2-8. doi:10.1332/030557312X655954.

Chen, M. (2011a). The response of hotel performance to international tourism development and crisis events. International Journal of Hospitality Management, 30(1), 200-212. doi:10.1016/j.ijhm.2010.06. 005 .

Chen, S. C. (2011b). Residents' perceptions of the impact of major annual tourism events in Macao: Cluster analysis. Journal of Convention and Event Tourism, 12(2), 106-128. doi:10.1080/15470148.2011. 569877.

Cheng, C., Li, X., Petrick, J., \& O’Leary, J. (2011). An examination of tourism journal development. Tourism Management, 32(1), 53-61. doi:10.1016/j.tourman.2009.11.004.

Cohen, E., \& Neal, M. (2010). Coinciding crises and tourism in contemporary Thailand. Current Issues in Tourism, 13(5), 455-475. doi:10.1080/13683500.2010.491898.

Cojocariu, S. (2010). Identification of special measures taken in tourism to reduce the economic impact of the economic crisis by the UE member states. Metalurgia International, 15, 101-104.

Connell, J. (2013). Medical tourism in the Caribbean Islands: A cure for economies in crisis? Island Studies Journal, 8(1), 115-130.

Cooper, C., \& Morpeth, N. (1998). The impact of tourism on residential experience in Central-Eastern Europe: The development of a new legitimation crisis in the Czech Republic. Urban Studies, 35(12), 2253-2275. doi:10.1080/0042098983872.

Costas, R., \& Bordons, M. (2007). The h-index: Advantages, limitations and its relation with other bibliometric indicators at the micro level. Journal of Informetrics, 1(3), 193-203. doi:10.1016/j.joi.2007. 02.001 . 
Ding, Y. (2011). Scientific collaboration and endorsement: Network analysis of coauthorship and citation networks. Journal of Informetrics, 5(1), 187-203. doi:10.1016/j.joi.2010.10.008.

Forsyth, T. J. (1991). Tourism-Problem or solution to the Himalayan crisis. Global Ecology and Biogeography Letters, 1(3), 65-68. doi:10.2307/2997491.

Galindo-Pérez-de-Azpillaga, L., Foronda-Robles, C., \& García-López, A. M. (2014). The value of trust: An analysis of social capital in natural areas. Social Indicators Research, 118(2), 673-694. doi:10.1007/ s11205-013-0427-3.

García, M. J., Chico, J. R., \& Sánchez, A. (2014). Incidencia de las zonas rurales sobre las posibles tipologías de turismo rural: el caso de Andalucía. Investigaciones Regionales, 28, 101-123.

Garfield, E. (2006). The history and meaning of the journal impact factor. JAMA, 295(1), 90-93. doi:10. 1001/jama.295.1.90.

Garfield, E., \& Sher, I. H. (1963). New factors in the evaluation of scientific literature through citation indexing. American Documentation, 14(3), 195-201. doi:10.1002/asi.5090140304.

Gilding, P. (2011). The great disruption: How the climate crisis will transform the global economy. London: Bloomsbury Press.

Gills, B. K. (2010). Globalization, crisis and transformation: World systemic crisis and the historical dialectics of capital. Globalizations, 7(1-2), 275-288. doi:10.1080/14747731003593737.

Giménez-Toledo, E., Tejada-Artigas, C., \& Mañana-Rodríguez, J. (2013). Evaluation of scientific books' publishers in social sciences and humanities: Results of a survey. Research Evaluation, 22(1), 64-77. doi:10.1093/reseval/rvs036.

Gómez Caridad, I., \& Bordons, M. (2009). Limitaciones en el uso de los indicadores bibliométricos para la evaluación científica. Date of consultation: 26/10/2014. http://digital.csic.es/bitstream/10261/9813/1/ 20090122134420909.pdf

González-Herrero, A., \& Pratt, C. B. (1998a). Differences in crisis-management strategies in tourism in the United States and Spain. Psychological Reports, 82(1), 73-74. doi:10.2466/pr0.1998.82.1.73.

González-Herrero, A., \& Pratt, C. B. (1998b). Marketing crises in tourism: Communication strategies in the United States and Spain. Public Relations Review, 24(1), 83-97. doi:10.1016/S0363-8111(98)80022-2.

Goodman, N. (2000). Survey of active verbs in the titles of clinical trial reports. BMJ, 320(7239), 914-915. doi:10.1136/bmj.320.7239.914.

Granda-Orive, J. I., Alonso-Arroyo, A., Villanueva-Serrano, S. J., Aleixandre-Benavent, R., GonzálezAlcaide, G., Garcia-Río, F., \& Roig-Vazquez, F. (2011). Comparación entre dos quinquenios (1998/ 2002 y 2003/2007) de la producción, repercusión y colaboración en tabaquismo de autores españoles a través del Science Citation Index. Archivos de Bronconeumología, 47(1), 25-34. doi:10.1016/j.arbres. 2010.09.006.

Greve, B. (Ed.). (2012). The times they are changing: Crisis and the welfare state (Vol. 8). New York: Wiley.

Gursoy, D., \& Sandstrom, J. (2014). An updated ranking of hospitality and tourism journals. Journal of Hospitality and Tourism Research,. doi:10.1177/1096348014538054.

Habibzadeh, F., \& Yadollahie, M. (2008). Journal weighted impact factor: A proposal. Journal of Informetrics, 2(2), 164-172. doi:10.1016/j.joi.2008.02.001.

Haggan, M. (2004). Research paper titles in literature, linguistics and science: Dimensions of attraction. Journal of Pragmatics, 36(2), 293-317. doi:10.1016/S0378-2166(03)00090-0.

Hall, M. (2005). Systems of surveillance and control: Commentary on 'An analysis of institutional contributors to three major academic tourism journals: 1992-2001'. Tourism Management, 26(5), 653-656. doi:10.1016/j.tourman.2004.05.002.

Hall, M. (2010). Crisis events in tourism: Subjects of crisis in tourism. Current Issues in Tourism, 13(5), 401-417. doi:10.1080/13683500.2010.491900.

Hall, M. (2011). Publish and perish? Bibliometric analysis, journal ranking and the assessment of research quality in tourism. Tourism Management, 32(1), 16-27. doi:10.1016/j.tourman.2010.07.001.

Hartley, J. (2007). Planning that title: Practices and preferences for titles with colons in academic articles. Library and Information Science Research, 29(4), 553-568. doi:10.1016/j.lisr.2007.05.002.

Headey, D. (2011). Rethinking the global food crisis: The role of trade shocks. Food Policy, 36(2), 136-146. doi:10.1016/j.foodpol.2010.10.003.

Headey, D. (2013). The impact of the global food crisis on self-assessed food security. The World Bank Economic Review, 27(1), 1-27. doi:10.1093/wber/lhs033.

Hirsch, J. E. (2007). Does the H index have predictive power? Proceedings of the National Academy of Sciences of the United States of America, 104(49), 19193-19198. doi:10.1073/pnas.0707962104.

Hoeffel, C. (1998). Journal impact factors. Allergy, 53(12), 1225. doi:10.1111/j.1398-9995.1998.tb03848.x. 
Hoekman, J., Frenken, K., \& Tijssen, R. (2010). Research collaboration at a distance: Changing spatial patterns of scientific collaboration within Europe. Research Policy, 39(5), 662-673. doi:10.1016/j. respol.2010.01.012.

Huang, X., Zhou, H., \& Zhu, H. (2012). Assessing the systemic risk of a heterogeneous portfolio of banks during the recent financial crisis. Journal of Financial Stability, 8(3), 193-205. doi:10.1016/j.jfs.2011. 10.004.

Huerta, M. G., \& Maldonado, L. K. (2011). Hacia la construcción de nuevos enfoques sobre globalización y crisis. Problemas del Desarrollo. Revista Latinoamericana de Economía, 42(164), $25-53$.

Hung, K., \& Law, R. (2011). An overview of internet-based surveys in hospitality and tourism journals. Tourism Management, 32(4), 717-724. doi:10.1016/j.tourman.2010.05.027.

Iñigo, J., \& Chaves, F. (2012). Análisis bibliométrico de las publicaciones en enfermedades infecciosas. Estudio comparativo de diez países en el periodo 2000-2009. Enfermedades Infecciosas y Microbiología Clínica, 30(5), 236-242. doi:10.1016/j.eimc.2011.10.017.

Jallat, F., \& Shultz, C. J. (2011). Lebanon: From cataclysm to opportunity-Crisis management lessons for MNCs in the tourism sector of the Middle East. Journal of World Business, 46(4), 476-486. doi:10. 1016/j.jwb.2010.10.008.

Jamal, T., Smith, B., \& Watson, E. (2008). Ranking, rating and scoring of tourism journals: Interdisciplinary challenges and innovations. Tourism Management, 29(1), 66-78. doi:10.1016/j.tourman.2007.04.001.

Jogaratnam, G., Chon, K., Mccleary, K., Mena, M., \& Yoo, J. (2005). An analysis of institutional contributors to three major academic tourism journals: 1992-2001. Tourism Management, 26(5), 641-648. doi:10.1016/j.tourman.2004.04.002.

Johannesson, G. T., \& Huijbens, E. H. (2010). Tourism in times of crisis: Exploring the discourse of tourism development in Iceland. Current Issues in Tourism, 13(5), 419-434. doi:10.1080/13683500.2010. 491897.

Jordà, Ò., \& Taylor, A. (2013). The time for austerity: Estimating the average treatment effect of fiscal policy. National Bureau of Economic Research, 25, 1-35.

Koseoglu, M. A. (2016). Mapping the institutional collaboration network of strategic management research: 1980-2014. Scientometrics, . doi:10.1007/s11192-016-1894-5.

Kotz, D. (2009). The financial and economic crisis of 2008: A systemic crisis of neoliberal capitalism. Review of Radical Political Economics, . doi:10.1177/0486613409335093.

Kriesi, H. (2012). The political consequences of the financial and economic crisis in Europe: Electoral punishment and popular protest. Swiss Political Science Review, 18(4), 518-522. doi:10.1111/spsr. 12006.

Larivière, V., \& Gingras, Y. (2010). The impact factor's Matthew effect: A natural experiment in bibliometrics. Journal of the American Society for Information Science and Technology, 61(2), 424-427. doi:10.1002/asi.21232.

Lasanta Martínez, T., \& García Ruiz, J. M. (2013). La producción de la geografía española a través de las bases de datos de Scopus e ISI Web of Knowledge. La investigación geográfica en España (19902012), pp. 221-234.

Lazar, C., \& Lazar, M. (2009). Short term forecasting methods applied in economy in crisis situations. Case study on Romanian tourism. Metalurgia International, 14, 171-173.

Lee, B., Kwon, O., \& Kim, H. J. (2011). Identification of dependency patterns in research collaboration environments through cluster analysis. Journal of Information Science, 37(1), 67-85. doi:10.1177/ 0165551510392147.

Li, S., Blake, A., \& Cooper, C. (2010). China's tourism in a global financial crisis: A computable general equilibrium approach. Current Issues in Tourism, 13(5), 435-453. doi:10.1080/13683500.2010. 491899.

Lillo-Banuls, A., \& Casado-Díaz, J. M. (2012). Individual returns to education in the Spanish tourism sector during the economic crisis. Tourism Economics, 18(6), 1229-1249. doi:10.5367/te.2012.0171.

Ma, Z. X., \& Liu, X. (2011). Evaluation and statistical analysis on the centrality indexes of tourism central city in the Central Liaoning urban clusters. Advanced Materials Research, 171, 671-674.

McKercher, B. (2005). A case for ranking tourism journals. Tourism Management, 26(5), 649-651. doi:10. 1016/j.tourman.2004.04.003.

Moed, H. F. (1996). Differences in the construction of SCI based bibliometric indicators among various producers: A first over view. Scientometrics, 35(2), 177-191. doi:10.1007/BF02018476.

Morakabati, Y. (2013). Tourism in the Middle East: Conflicts, crises and economic diversification, some critical issues. International Journal of Tourism Research, 15(4), 375-387. doi:10.1002/jtr.1882.

Motahedin, M. (2012). Influence of economic world crisis in tourism negative growth in Tajikistan with short look at tourism destinations. Life Science Journal-Acta Zhengzhou University Overseas Edition, 9(4), 86-88. 
Muenster, D., \& Muenster, U. (2012). Consuming the forest in an environment of crisis: Nature tourism, forest conservation and neoliberal agriculture in South India. Development and Change, 43(1), 205-227. doi:10.1111/j.1467-7660.2012.01754.x.

Navarro, V. (2013). The social crisis of the Eurozone: The case of Spain. International Journal of Health Services, 43(2), 189-192. doi:10.2190/HS.43.2.a.

Newman, M. (2001). The structure of scientific collaboration networks. Proceedings of the National Academy of Sciences, 98(2), 404-409. doi:10.1073/pnas.98.2.404.

Nunkoo, R., Gursoy, D., \& Ramkissoon, H. (2013). Developments in hospitality marketing and management: Social network analysis and research themes. Journal of Hospitality Marketing and Management, 22, 269-288. doi:10.1080/19368623.2013.753814.

O'Brien, A. (2012). Wasting a good crisis: Developmental failure and Irish tourism since 2008. Annals of Tourism Research, 39(2), 1138-1155. doi:10.1016/j.annals.2011.12.008.

Okumus, F., Altinay, M., \& Arasli, H. (2005). The impact of Turkey's economic crisis of February 2001 on the tourism industry in northern Cyprus. Tourism Management, 26(1), 95-104. doi:10.1016/j.tourman. 2003.08.013.

Ozturk, S., Sozdemir, A., \& Ulger, O. (2013). The real crisis waiting for the world: Oil problem and energy security. International Journal of Energy Economics and Policy, 3, 74-79.

Page, S., Song, H., \& Wu, D. C. (2012). Assessing the impacts of the global economic crisis and swine flu on inbound tourism demand in the United Kingdom. Journal of Travel Research, 51(2), 142-153. doi:10. $1177 / 0047287511400754$.

Papatheodorou, A., Rossello, J., \& Xiao, H. (2010). Global economic crisis and tourism: Consequences and perspectives. Journal of Travel Research, 49(1), 39-45. doi:10.1177/0047287509355327.

Paraskevas, A., \& Altinay, L. (2013). Signal detection as the first line of defence in tourism crisis management. Tourism Management, 34, 158-171. doi:10.1016/j.tourman.2012.04.007.

Paraskevas, A., Altinay, L., Mclean, J., \& Cooper, C. (2013). Crisis knowledge in tourism: Types, flows and governance. Annals of Tourism Research, 41, 130-152. doi:10.1016/j.annals.2012.12.005.

Park, J., Conca, K., \& Finger, M. (2008). The crisis of global environmental governance: Towards a new political economy of sustainability. London: Routledge.

Pechlaner, H., Zehrer, A., Matzler, K., \& Abfalter, D. (2004). A ranking of international tourism and hospitality journals. Journal of Travel Research, 42, 328-332. doi:10.1177/0047287504263026.

Pennington-Gray, L., Thapa, B., Kaplanidou, K., Cahyanto, I., \& McLaughlin, E. (2011). Crisis planning and preparedness in the United States tourism industry. Cornell Hospitality Quarterly, 52(3), 312-320. doi:10.1177/1938965511410866.

Prideaux, B., Laws, E., \& Faulkner, B. (2003). Events in Indonesia: Exploring the limits to formal tourism trends forecasting methods in complex crisis situations. Tourism Management, 24(4), 475-487. doi:10. 1016/S0261-5177(02)00115-2.

Prideaux, B., \& McNamara, K. E. (2013). Turning a global crisis into a tourism opportunity: The perspective from Tuvalu. International Journal of Tourism Research, 15(6), 583-594. doi:10.1002/jtr.1883.

Racherla, P., \& Hu, C. (2009). A framework for knowledge-based crisis management in the hospitality and tourism industry. Cornell Hospitality Quarterly, 50(4), 561-577. doi:10.1177/1938965509341633.

Racherla, P., \& Hu, C. (2010). A social network perspective of tourism research collaborations. Annals of Tourism Research, 37(4), 1012-1034. doi:10.1016/j.annals.2010.03.008.

Ravn, M., \& Sterk, V. (2012). Job uncertainty and deep recessions. Working paper. University College London, 2012. Date of consultation: 15/10/2014. https://www.economicdynamics.org/meetpapers/ 2013/paper_921.pdf

Rendahl, P. (2012). Fiscal policy in an unemployment crisis. Cambridge working papers in economics 1211. Date of consultation: 05/10/2014. http://www.econ.cam.ac.uk/dae/repec/cam/pdf/cwpe1211.pdf

Ritchie, B. W. (2004). Chaos, crises and disasters: A strategic approach to crisis management in the tourism industry. Tourism Management, 25(6), 669-683. doi:10.1016/j.tourman.2003.09.004.

Ritchie, J. R. B., Amaya Molinar, C. M., \& Frechtling, D. C. (2010). Impacts of the world recession and economic crisis on tourism: North America. Journal of Travel Research, 49(1), 5-15. doi:10.1177/ 0047287509353193.

Rittichainuwat, B. N. (2013). Tourists' and tourism suppliers' perceptions toward crisis management on tsunami. Tourism Management, 34, 112-121. doi:10.1016/j.tourman.2012.03.018.

Ryan, C. (2005). The ranking and rating of academics and journals in tourism research. Tourism Management, 26(5), 657-662. doi:10.1016/j.tourman.2004.05.001.

Sandoval, E. C., Zárraga, L., \& Ruiz, J. G. (2015). Innovación en el Sector Turismo de Cancún: Evidencias Empíricas (Innovation in the Tourism Sector in Cancun: Empirical Evidence). Revista Internacional Administración \& Finanzas, 8(4), 93-105. 
Sausmarez, N. (2013). Challenges to Kenyan tourism since 2008: Crisis management from the Kenyan tour operator perspective. Current Issues in Tourism, 16(7-8), 792-809. doi:10.1080/13683500.2013. 785488.

Seglen, P. O. (1997). Why the impact factor of journals should not be used for evaluating research. British Medical Journal, 314(7079), 498-502.

Seppälä, J., \& Hämäläinen, R. P. (2001). On the meaning of the distance-to-target weighting method and normalisation in life cycle impact assessment. The International Journal of Life Cycle Assessment, 6(4), 211-218. doi:10.1007/BF02979376.

Smeral, E. (2009). The impact of the financial and economic crisis on European tourism. Journal of Travel Research, 48(1), 3-13. doi:10.1177/0047287509336332.

Smeral, E. (2010). Impacts of the world recession and economic crisis on tourism: Forecasts and potential risks. Journal of Travel Research, 49(1), 31-38. doi:10.1177/0047287509353192.

Song, H., \& Lin, S. (2010). Impacts of the financial and economic crisis on tourism in Asia. Journal of Travel Research, 49(1), 16-30. doi:10.1177/0047287509353190.

Stafford, J. (2003). The tourism research crisis: The solution lies in the problems. Loisir et Société/Society and Leisure, 26(1), 87-95. doi:10.1080/07053436.2003.10707607.

Sydserff, R., \& Weetman, P. (2002). Developments in content analysis: A transitivity index and scores. Accounting, Auditing and Accountability Journal, 15(4), 523-545.

Unwto. (2009). World Tourism Barometer: Interim update, April 2009. www.e-unwto.org

Van Doren, C. S., Koh, Y. K., \& McCahill, A. (1994). Tourism research: A state-of-the art citation analysis (1971-1990). In A. V. Seaton (Ed.), Tourism: The state of the art (pp. 308-315). Chichester: Wiley.

Van Leeuwen, T. (2006). The application of bibliometric analyses in the evaluation of social science research. Who benefits from it, and why it is still feasible. Scientometrics, 66(1), 133-154.

Vinkler, P. (1988). Weighted impact of publications and relative contribution score. Two new indicators characterizing publication activity of countries. Scientometrics, 14(1-2), 161-163. doi:10.1007/ BF02020249.

Vles, V. (2012). Ski resorts in crisis and territorial construction in French Catalonia. Inter-municipal management of tourism resources-Has the debate been hijacked? Revue de Géographie Alpinel Journal of Alpine Research, 100(1-4), 225-238.

Wagner, W. (2010). Diversification at financial institutions and systemic crises. Journal of Financial Intermediation, 19(3), 373-386. doi:10.1016/j.jfi.2009.07.002.

Waltman, L., \& Van Eck, N. J. (2012). The inconsistency of the h-index. Journal of the American Society for Information Science and Technology, 63(2), 406-415. doi:10.1002/asi.21678.

Wan, H. (2008). Resonance as a mediating factor accounting for the message effect in tailored communication: Examining crisis communication in a tourism context. Journal of Communication, 58(3), 472-489. doi:10.1111/j.1460-2466.2008-00395.x.

Wang, Y. (2009). The impact of crisis events and macroeconomic activity on Taiwan's international inbound tourism demand. Tourism Management, 30(1), 75-82. doi:10.1016/j.tourman.2008.04.010.

Wang, Y., \& Bai, Y. (2007). A corpus-based syntactic study of medical research article titles. System, 35(3), 388-399. doi:10.1016/j.system.2007.01.005.

Weiner, G. (2001). The academic journal: Has it a future? Education Policy Analysis Archives, 9(9), 1-19. doi:10.14507/epaa.v9n9.2001.

Wergin, C. (2012). Trumping the ethnic card: How tourism entrepreneurs on Rodrigues tackled the 2008 financial crisis. Island Studies Journal, 7(1), 119-134.

Xiao, H., \& Smith, S. L. J. (2006). The making of tourism research: Insights from a social sciences journal. Annals of Tourism Research, 33(2), 490-507. doi:10.1016/j.annals.2006.01.004.

Yarcan, S. (2007). Coping with continuous crises: The case of Turkish inbound tourism. Middle Eastern Studies, 43(5), 779-794. doi:10.1080/00263200701422691.

Yi, H., \& Jie, W. (2011). A bibliometric study of the trend in articles related to eutrophication published in Science Citation Index. Scientometrics, 89(3), 919-927.

Zhao, W., \& Ritchie, J. R. B. (2007). An investigation of academic leadership in tourism research: 1985-2004. Tourism Management, 28, 476-490. doi:10.1016/j.tourman.2006.03.007.

Zitt, M., \& Small, H. (2008). Modifying the journal impact factor by fractional citation weighting: The audience factor. Journal of the American Society for Information Science and Technology, 59(11), 1856-1860. doi:10.1002/asi.20880. 